\title{
Occurrence of Pharmaceuticals and Disinfectants in the Dissolved Water Phase of the Danube River and Three Major Tributaries from Romania
}

\author{
JANA PETRE $^{1 *}$, VASILE-ION IANCU ${ }^{1,2}$, TOMA GALAON ${ }^{1}$, MARIUS SIMION ${ }^{1}$, MARCELA \\ NICULESCU ${ }^{1}$, GABRIELA GEANINA VASILE ${ }^{1}$, LUOANA FLORENTINA PASCU ${ }^{1}$, CAROL \\ BLAZIU LEHR $^{1}$, LILIANA CRUCERU ${ }^{1}$, SIMONA CALINESCU, GABRIEL-LUCIAN RADU ${ }^{2}$
}

\author{
${ }^{I}$ National Research and Development Institute for Industrial Ecology ECOIND Bucharest, 71-73 Drumul Podul Dambovitei, 060652, \\ Bucharest, Romania \\ ${ }^{2}$ University Politehnica Bucharest, Faculty of Applied Chemistry and Materials Science, 1-7 Polizu Str., 011061, Bucharest, \\ Romania \\ *correspondence author (e-mail): janapetre@gmail.com
}

The presence of pharmaceuticals in the aquatic ecosystem has received great attention from the scientific community in the last decades, due to their potential impact on living organisms. This paper presents a short review of the results of investigations performed by INCD-ECOIND concerning the occurrence of 32 pharmaceutical compounds belonging to important therapeutic classes and 2 disinfectants along the Danube River and its tributaries. Grab water samples were collected from multiple points along the River (10 sites) and from 2 locations for each of the tributaries Jiu, Olt and Argeș, upstream and downstream of large cities. All samples were quantified via solid phase extraction, followed by liquid chromatography-tandem mass spectrometry (LC-MS/MS). Results of these studies show that various pharmaceutical compounds are present in the dissolved water phase of the Danube River and its tributaries in low to moderate amounts with variation due to season and location.

Keywords: pharmaceuticals, disinfectants, surface waters, Danube River, tributaries

In recent years, pharmaceutical compounds have been recognized as a new class of contaminants for water resources, with adverse effects on aquatic and terrestrial life.

The presence and concentration levels of pharmaceuticals in natural waters require investigation in order to assess their potential to disturb the equilibrium of the aquatic environment. Thus, a continuous exposure of bacterial fauna, even to very low concentrations of antibiotics, can lead to the persistence of resistant bacterial strains [1]. Also, the exposure of aquatic organisms to endocrine disrupting chemicals, for instance estrogen hormones can affect the reproduction and development of these living organisms [2]. Some studies reported that bacteria isolated from treated sewage sludge have shown resistance to several antibiotics including ampicillin, tetracycline, ciprofloxacin, trimethoprim and erythromycin [3,4]. Animal and fish farms, where antibiotics are administered as feed additives and for therapeutic purposes, are also sources of drugresistant bacteria [5]. Nowadays there are numerous pathways through which pharmaceutical compounds reach the aquatic environment (depicted in Figure 1). Effluents of the municipal wastewater treatment plants (WWTPs) are a major source of continuous introduction of numerous human pharmaceutical compounds in natural waters. Unused or expired drugs not properly landfilled are also a potential source of contamination of surface waters. Moreover, runoffs from agricultural fields, livestock from farms and fish ponds may contain pharmaceutical residues which end up in the aquatic environment [6]. 


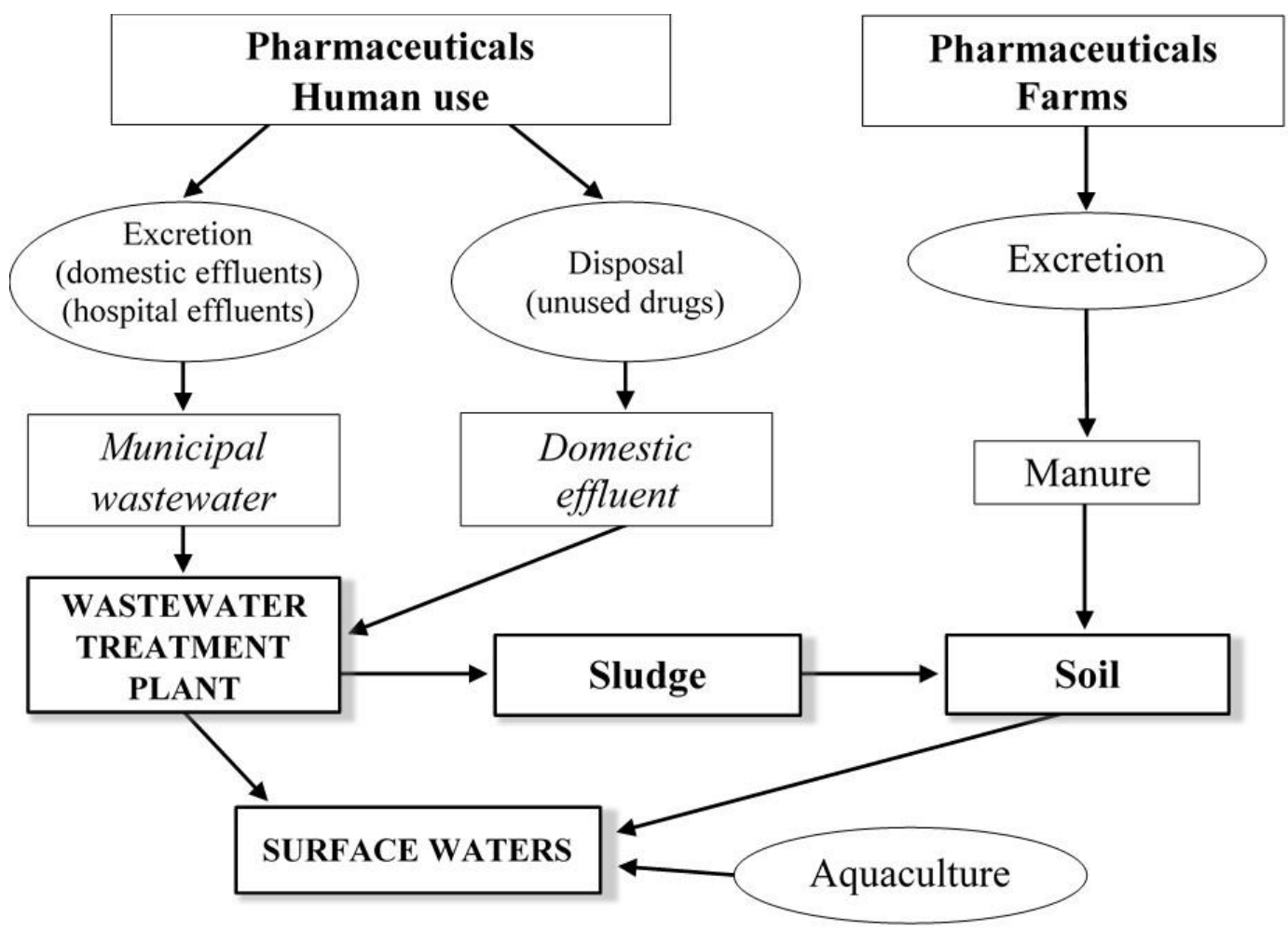

Fig.1. Source of pharmaceuticals in the aquatic environment

A number of pharmaceutical compounds, once arrived in the aquatic environment, suffer a decrease in concentration either by dilution, adsorption on solids, or by biochemical decomposition, whilst other compounds are resistant to degradation and may persist, and end up accumulating in living organisms. Contamination of natural waters with pharmaceutical products has a direct impact on aquatic organisms causing the extinction of sensible species, and ultimately a decline in biodiversity. Due to the risks connected with the ubiquity of various pollutants in natural waters, the European Union established a watchlist of substances or groups of substances found to be a threat to the safety of the aquatic environment. [7]. This list is updated every two years and the latest one approved by the European Commission (EU Decision 2018/840) includes the following pharmaceuticals: $17 \alpha-$ ethinylestradiol, $\quad 17 \beta$-estradiol, estrone, erythromycin, amoxicillin, clarithromycin, azithromycin and ciprofloxacin. These new rules amend the Water Framework Directive (WFD 2000/60/EC) as well as the Directive (2008/105/EC). The presence of pharmaceutical compounds in the aquatic environment has caught the attention of the scientific world due to its threat on the health of aquatic organisms. This resulted in an increased number of reports concerning the concentrations of the pharmaceutical compounds detected in WWTP effluent samples as well as in the emissaries.

It is known that the removal efficiency of the wastewater treatment process can vary and is influenced by the specific characteristics of the drugs in question and also by other factors such as hydraulic retention time, environmental conditions and age of the activated sludge [810]. It has been noticed that conjugation and deconjugation processes occur in the treatment plants and therefore, it is observed an increase in the initial concentrations of the pharmaceutical compounds after the treatment process occurs. It should be emphasized that in the WWTP effluents the pharmaceuticals and disinfectants are present in complex mixtures together with their metabolites and their transformation products [11].

Pharmaceuticals often detected in some conventional WWTP effluents are listed in Table 1, with their reported concentration range [12]. 
Table 1. Presence of pharmaceuticals and disinfectants in WWTP effluents.

\begin{tabular}{lccc}
\hline \multicolumn{1}{c}{ Pharmaceuticals } & $\begin{array}{c}\text { Concentration } \\
(\mathbf{n g} / \mathbf{L})\end{array}$ & Country & References \\
\hline Sulfamethoxazole & BQL-34.4 & Greece & {$[13]$} \\
& $19-198$ & Spain & {$[14]$} \\
\hline Trimethoprim & BQL-27.4 & Greece & {$[13]$} \\
\hline Ofloxacin & BQL-108 & Spain & {$[14]$} \\
\hline Clarithromycin & $63-101$ & Spain & {$[14]$} \\
\hline Norfloxacin & $172-229$ & Spain & {$[14]$} \\
\hline \multirow{2}{*}{ Triclosan } & BDL-149 & Spain & {$[14]$} \\
\hline \multirow{2}{*}{ Azithromycin } & $3.89-15.4$ & Portugal & {$[15]$} \\
\hline Erythromycin & BQL -111,2 & Greece & {$[13]$} \\
\hline
\end{tabular}

BQL-Below Quantification Limit; BDL-Below Detection Limit

Danube River is a large stream receiving high anthropogenic inputs and whose water is at the same time an important source of drinking water for riparian population, in some cases without being subjected to any treatment process. Therefore, there is a need of data on the presence of these contaminants in the Romanian part of the Danube River basin. The aim of these works conducted by INCD-ECOIND and summarized in this short review article, was to document the occurrence of selected pharmaceuticals along the Romanian part of the Danube River and assess the contribution of its three main tributaries: Jiu, Olt and Argeș.

Presence of pharmaceuticals and disinfectants in WWTP effluents

Conventional treatment plants, mostly used in Romania, are not designed to completely remove organic compounds, such as the pharmaceuticals with lower levels of concentration, which can be found in wastewaters.

In this paper [17] we investigated the occurrence and removal of nine pharmaceuticals in the WWTP of Bucharest. The influent and effluent samples were $24 \mathrm{~h}$ composites and were collected using flow proportional samples during a nine-day period in the autumn of 2012 . The compounds investigated in this study were acetaminophen (ACE), caffeine (CAF), trimethoprim (TRI), norfloxacin (NOR), ciprofloxacin (CIP), azithromycin (AZI), sulfamethoxazole (SMX), erythromycin (ERY) and carbamazepine (CBZ). The concentration ranges of pharmaceuticals found in influent and effluent samples are presented in Table 2.

Table 2. Concentrations of pharmaceuticals in influent and effluent samples of WWTP of

\begin{tabular}{ccc}
\hline Compound & $\begin{array}{c}\text { Influent } \\
(\boldsymbol{\mu g} / \mathbf{L})\end{array}$ & $\begin{array}{c}\text { Effluent } \\
(\boldsymbol{\mu g} / \mathbf{L})\end{array}$ \\
\hline ACE & $8.96-30.16$ & $0.42-5.03$ \\
\hline CAF & $21.78-74.54$ & $2.82-11.64$ \\
\hline CBZ & $0.31-2.34$ & $0.71-1.57$ \\
\hline CIP & $<$ LOD - 4.97 & $<$ LOD - 1.83 \\
\hline SMX & $0.30-0.73$ & $0.13-0.61$ \\
\hline TRI & $0.05-0.50$ & $0.19-0.49$ \\
\hline AZI & $<$ LOD - 0.49 & $<$ LOD - 0.15
\end{tabular}

Abbreviations: ACE: acetaminophen, CAF: caffeine, CBZ: carbamazepine, CIP: ciprofloxacin, SMX: sulfamethoxazole, TRI: trimethoprim, AZI: azithromycin 


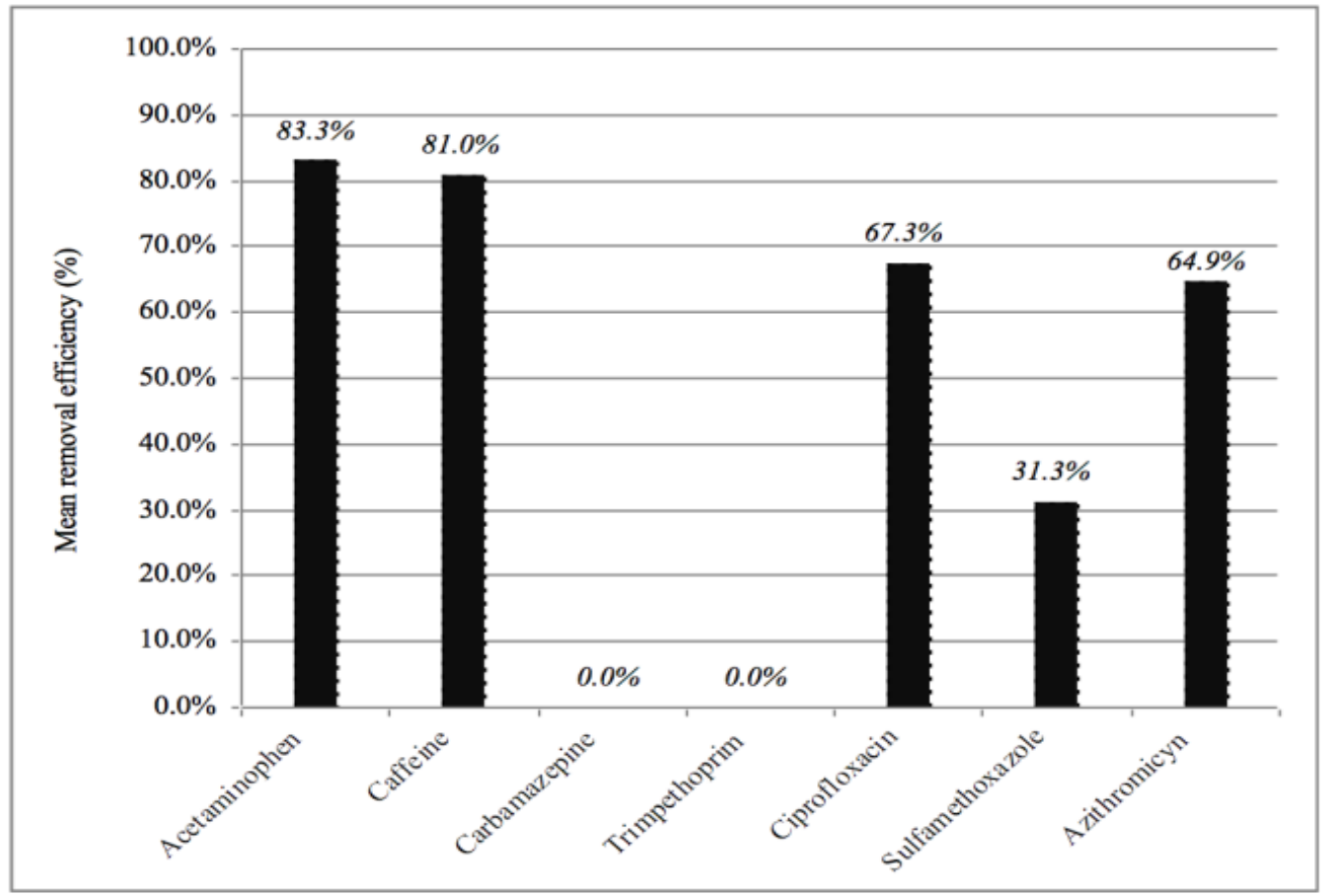

Fig. 2. Mean removal efficiencies (\%) of detected pharmaceuticals in Bucharest WWTP

ERY and NOR were not detected in the analyzed samples, probably due to their limited usage during the period of investigation. Excepting CIP and AZI, all compounds were ubiquitous in WWTP influent and effluent samples. The most abundant one was caffeine. This widely used compound was found in effluents in concentrations ranging from 2.82 $\mu \mathrm{g} / \mathrm{L}$ to $11.64 \mu \mathrm{g} / \mathrm{L}$. In effluent samples CBZ concentration varied from $0.71 \mu \mathrm{g} / \mathrm{L}$ to 1.57 $\mu \mathrm{g} / \mathrm{L}$, similar to $1.18 \mu \mathrm{g} / \mathrm{L}$ found in Källby WWTP in Sweden [18]. Similar concentrations of SMX and TRI were observed at WWTPs effluents in Spain [14], these two pharmaceuticals being used in the same drug. Mean removal rates of the compounds determined in this work, calculated as the difference between 9 days mean concentrations of each compound in the influent and effluent samples are depicted in Figure 2.

ACE and CAF had the highest average elimination yields of $83.3 \%$ and $81.0 \%$, respectively. Low or no removal rates of CBZ were also previously reported $[19,20]$. This organic compound is known as being very persistent to biodegradation, even at low concentrations. An increase in CBZ, TRI and SMX concentrations in the effluent samples was observed, a phenomenon also reported in other studies [20-22].

The fluctuation of the concentrations during the sampling period [21] and the deconjugation of conjugated metabolites during the treatment process [22] are among the possible explanations.

Another investigation was carried out in the effluents of municipal WWTP of the City of Brăila, having the Danube River as natural receiver [23]. Treatments in this WWTP include primary settling and biological processing (activated sludge). All samples were grab samples and were collected between the 16th and the 20th of November 2015.

The studied compounds were diclofenac (DCF), ketoprofen (KET), piroxicam (PIR), ibuprofen (IBU), naproxen (NPX), hydrochlorothiazide (HCT), furosemide (FUR), triclosan (TCS), triclocarban (TCC), and gemfibrozil (GEM).

The results showed that all effluent samples contained pharmaceuticals and disinfectants. Only IBU was not detected in any of the analysed samples. Maximum concentrations were determined for PIR, with average concentration of $103 \mathrm{ng} / \mathrm{L}$. TCS and TCC, the disinfectants investigated in samples from effluents were found in average concentrations of $15.6 \mathrm{ng} / \mathrm{L}$ and $14.1 \mathrm{ng} / \mathrm{L}$, respectively.

\section{Occurrence of pharmaceuticals in surface water of Danube River and tributaries}

In several investigations conducted in INCDECOIND since 2012, the presence and fate of 32 
pharmaceuticals belonging to various therapeutic classes and 2 disinfectants were investigated in the dissolved water phase of river water at 16 sampling locations along the Romanian side of the Danube and its three main tributaries, Jiu, Olt and Argeș rivers [24-26].

Sampling sites and sample collection

Several sampling campaigns were performed from February 2014 to October 2015. Samples were collected from 10 locations along the Romanian part of the Danube River and 2 locations from each of its 3 tributaries as follows: (a) Jiu river - upstream and downstream Craiova city; (b) Olt river - downstream Slatina and a site closed to its confluence with Danube; (c) Argeș river - downstream Pitești city and a site closed to its confluence with Danube, according to Figure 3. All samples were grab samples and were taken from a depth of approximately $0.5 \mathrm{~m}$ to $2 \mathrm{~m}$ from the riverbank with the exception of samples from sites S3, S7, $\mathrm{S} 11$ and $\mathrm{S} 13$ which were sampled at $10 \mathrm{~m}$ from the bank, by being gathered from a bridge. Location data, GPS coordinates and descriptions are given in Table 3. Investigated pharmaceuticals in these studies are: analgesics/anti-inflammatory drugs, antibiotics, diuretics, anti-epileptics, lipid regulators, nervous stimulant, disinfectants and estrogen hormones, due to their extensive prescription or usage. The individual compounds are presented in Figure 4.

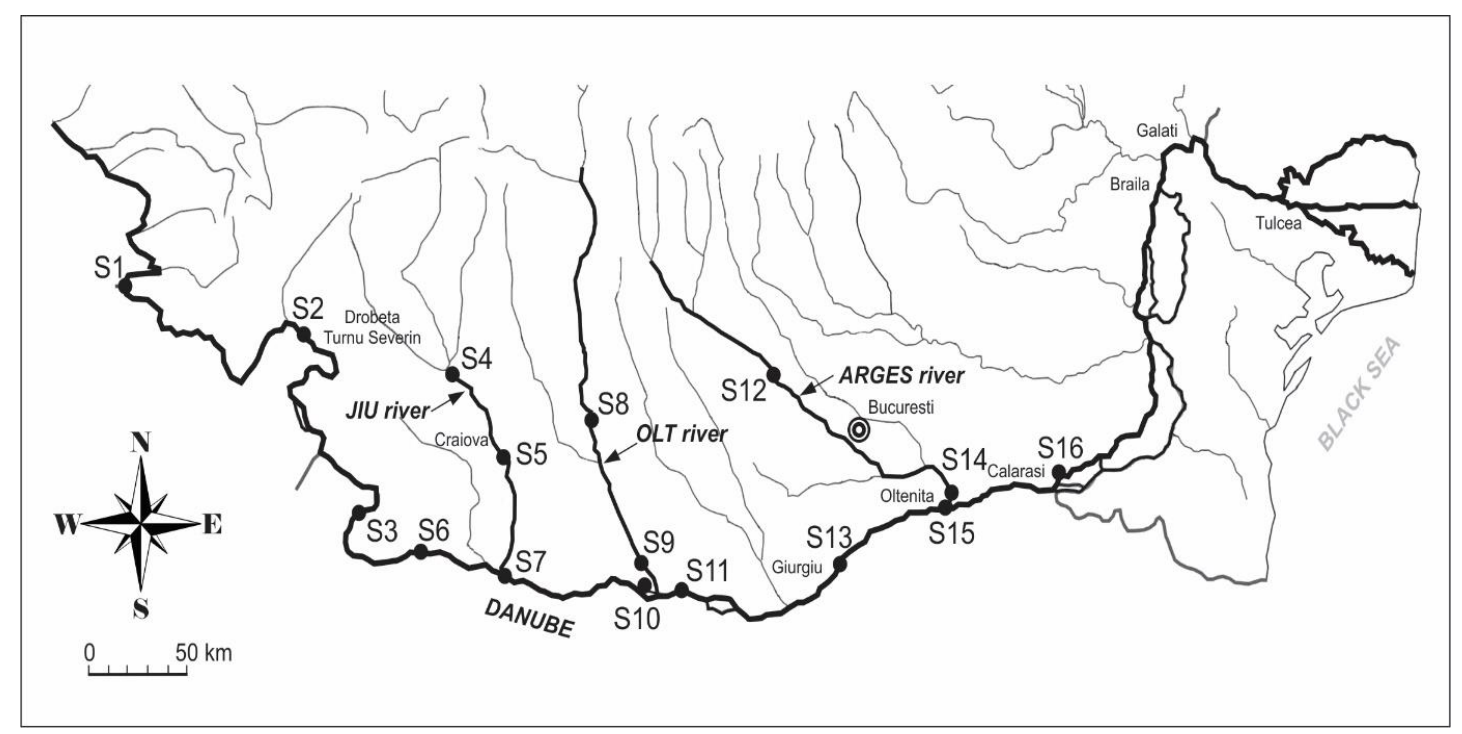

Fig. 3. Map of the sampling sites in the Danube River basin. $\mathrm{S}=$ sampling site

Table 3. Geographic location with GPS coordinates and description of sampling sites.

\begin{tabular}{|c|c|c|}
\hline Sampling point & River & GPS coordinates \\
\hline S1- Bazias & Danube & $44^{\circ} 47^{\prime} 32.61^{\prime \prime N} ; 21^{\circ} 23^{\prime} 20.07^{\prime \prime E}$ \\
\hline S2- Gura Vaii, upstream Drobeta Turnu Magurele & Danube & $44^{\circ} 40^{\prime} 7.40^{\prime \prime} \mathrm{N} ; 22^{\circ} 33^{\prime} 10.74^{\prime \prime} \mathrm{E}$ \\
\hline S3- Calafat & Danube & $43^{\circ} 57^{\prime} 50.94 " \mathrm{~N} ; 22^{\circ} 54^{\prime} 15.72^{\prime \prime} \mathrm{E}$ \\
\hline S4- Filiasi, upstream Craiova city & Jiu & $44^{\circ} 34^{\prime} 8.32^{\prime \prime} \mathrm{N} ; 23^{\circ} 27^{\prime} 18.14^{\prime \prime} \mathrm{E}$ \\
\hline S5- Podari, downstream Craiova city & Jiu & $44^{\circ} 15^{\prime} 18.48^{\prime \prime N} ; 23^{\circ} 47^{\prime} 25.08^{\prime \prime E}$ \\
\hline S6- Rast, upstream of the confluence with Jiu river & Danube & $43^{\circ} 51^{\prime 2} 24.84^{\prime \prime N} ; 23^{\circ} 17^{\prime} 18.79^{\prime \prime} \mathrm{E}$ \\
\hline S7 -Bechet, downstream of the confluence with Jiu river & Danube & $43^{\circ} 45^{\prime} 11.32^{\prime \prime} \mathrm{N} ; 23^{\circ} 56^{\prime} 30.69^{\prime \prime} \mathrm{E}$ \\
\hline S8 -Downstream Slatina city & Olt & $44^{\circ} 23^{\prime} 29.63^{\prime \prime N} ; 24^{\circ} 21^{\prime} 4.84^{\prime \prime} \mathrm{E}$ \\
\hline stream of the confluence with Danube & Olt & $43^{\circ} 48^{\prime} 41.71^{\prime \prime} \mathrm{N} ; 24^{\circ} 42^{\prime} 27.71 " \mathrm{E}$ \\
\hline S10 -Islaz, & & $43^{\circ} 42^{\prime} 22.72^{\prime \prime} \mathrm{N} ; 24^{\circ} 44^{\prime} 4.01^{\prime \prime} \mathrm{E}$ \\
\hline downstream of the confluence with Olt river & Danube & $43^{\circ} 43^{\prime} 2.69^{\prime \prime} \mathrm{N} ; 24^{\circ} 48^{\prime} 56.65^{\prime \prime} \mathrm{E}$ \\
\hline S12 -Downstream Pitesti city & Arges & $44^{\circ} 28^{\prime} 45.25^{\prime \prime} \mathrm{N} ; 25^{\circ} 40^{\prime} 47.87^{\prime \prime} \mathrm{E}$ \\
\hline S13- Giurgiu, upstream of the confluence with Arges river & Danube & $43^{\circ} 52^{\prime} 37.50^{\prime \prime} \mathrm{N} ; 25^{\circ} 58^{\prime} 49.92^{\prime \prime} \mathrm{E}$ \\
\hline S14- upstream of the confluence with Danube river & Arges & $44^{\circ} 6^{\prime} 38.09^{\prime \prime N} ; 26^{\circ} 38^{\prime} 15.33^{\prime \prime E}$ \\
\hline S15 -Oltenita, downstream of the confluence with Arges river & Danube & $44^{\circ} 3{ }^{\prime} 51.89^{\prime \prime} \mathrm{N} ; 26^{\circ} 38^{\prime} 45.49^{\prime \prime} \mathrm{E}$ \\
\hline S16 -Calarasi & Danube & $44^{\circ} 8^{\prime} 15.69^{\prime \prime} \mathrm{N} ; 27^{\circ} 20^{\prime} 8.26^{\prime \prime} \mathrm{E}$ \\
\hline
\end{tabular}




\begin{tabular}{|c|c|c|}
\hline $\begin{array}{l}\text { Diuretics } \\
\text { Furosemide } \\
\text { Hydrochlorothiazide } \\
\text { Antiepileptics } \\
\text { Carbamazepine } \\
\text { Nevroses stimulant } \\
\text { Caffeine }\end{array}$ & $\begin{array}{l}\quad \text { Steroids } \\
\text { Estrone } \\
\text { Equilin } \\
17 \alpha \text {-estradiol } \\
17 \beta \text {-estradiol } \\
\text { Estriol } \\
17 \alpha \text {-ethinylestradiol }\end{array}$ & $\begin{array}{l}\quad \text { Antibiotics } \\
\text { Trimethoprim } \\
\text { Ciprofloxacin } \\
\text { Norfloxacin } \\
\text { Azithromycin } \\
\text { Erythromycin } \\
\text { Roxithromycin }\end{array}$ \\
\hline $\begin{array}{c}\text { Anti-inflammatory } \\
\text { drugs/analgesics }\end{array}$ & & Cephalexin \\
\hline Diclofenac & Pharmaceuticals & Penicillin $G$ \\
\hline $\begin{array}{l}\text { Ketoprofen } \\
\text { Ibuprofen }\end{array}$ & $\begin{array}{c}\text { and } \\
\text { Disinfectants }\end{array}$ & $\begin{array}{l}\text { Penicillin } V \\
\text { Oxacillin }\end{array}$ \\
\hline Piroxicam & & Ofloxacin \\
\hline $\begin{array}{l}\text { Naproxen } \\
\text { Acetaminophen }\end{array}$ & & Clarithromycin \\
\hline $\begin{array}{l}\text { Lipid regulators } \\
\text { Gemfibrozil }\end{array}$ & & $\begin{array}{l}\text { Disinfectants } \\
\text { Triclosan } \\
\text { Triclocarban }\end{array}$ \\
\hline
\end{tabular}

Fig. 4. Investigated pharmaceuticals and disinfectants

Sample treatment and analysis of the pharmaceuticals

Analytical protocol was based on previously optimized methods reported elsewhere [24-26]. Sample treatment was based on solid phase extraction with an enrichment factor of 500, and using internal labeled compounds. The chromatographic separations of compounds were performed on an Agilent 1260 series LC system (Agilent, Waldbronn, Germany) consisting of binary pump, thermostated autosampler and thermostated column compartment coupled with an Agilent 6410B triple-quadrupole mass analyzer fitted with an electrospray ionization source. Data acquisition and analysis were performed using Mass Hunter software, revision B.05.00. Target analytes detection was done in Multiple Reaction Monitoring (MRM) mode with dual polarity ( \pm ). Full scan MS mode coupled with different fragmentor voltage values was used to obtain product ion rich MS spectra for all analytes.

For each compound, two signals were monitored, corresponding to the transition between the precursor ion and the two most abundant product ions. The most abundant one was used for quantification while the other one was used for confirmation. Agilent Mass Hunter software was used for data acquisition and quantitative determinations.

\section{RESULTS AND DISCUSSIONS}

By using the optimized analytical methods, the undertaken studies showed that all investigated samples contained pharmaceutical compounds. During a first investigation, the samples were collected during the months of February, April and June 2014 and the following compounds were analyzed: diclofenac (DCF), ketoprofen (KET), piroxicam (PIR), ibuprofen (IBU), naproxen (NPX), hydrochlorotiazide (HCT), furosemide (FUR), triclosan (TCS), triclocarban (TCC) and gemfibrozil (GEM) [24]. The obtained results and detected percentages are presented in Table 4. 
Table 4. Concentration ranges and frequency of detected pharmaceuticals.

\begin{tabular}{c|ccccccccc}
\hline \multirow{2}{*}{ Analyte } & \multicolumn{3}{|c}{ Range (ng/L) } & \multicolumn{3}{c}{ Median \pm IQR $^{\mathbf{a}(\mathbf{n g} / \mathbf{L})}$} & \multicolumn{3}{c}{ Detection freq. (\%) } \\
\cline { 2 - 10 } & Feb. & Apr. & June & Feb. & Apr. & June & Feb. & Apr. & June \\
\hline DCF & $0.8-7.2$ & $1.3-7.5$ & $0.9-5.9$ & $1.9 \pm 1.4$ & $3.3 \pm 2.6$ & $2.1 \pm 1.6$ & 50 & 100 & 56 \\
\hline KET & $0.9-3.6$ & $0.8-8.4$ & $2.2-12.9$ & $1.8 \pm 0.6$ & $2.5 \pm 3.8$ & $6.4 \pm 4.1$ & 44 & 87 & 94 \\
\hline TCS & $1.7-9.1$ & $0.7-7.8$ & $1.9-18.4$ & $4.4 \pm 4.1$ & $2.7 \pm 3.2$ & $2.1 \pm 2.0$ & 62 & 100 & 50 \\
\hline TCC & $0.8-6.3$ & $0.8-54$ & $0.6-4.1$ & $2.4 \pm 1.7$ & $3.6 \pm 1.8$ & $1.5 \pm 1.2$ & 100 & 100 & 44 \\
\hline PIR & - & $0.7-1.6$ & - & - & $1.2 \pm 0.5$ & - & - & 37 & - \\
\hline IBU & - & - & $2.0-27.2$ & - & - & $11.9 \pm 5.5$ & - & - & 100 \\
\hline NPX & - & - & $2.4-106$ & - & - & $44.8 \pm 19.2$ & - & - & 100 \\
\hline
\end{tabular}

${ }^{\mathrm{a}} \mathrm{IQR}$-interquartile range

Only 7 compounds were determined in the analyzed water samples, namely: DCF, KET, TCS, TCC, PIR, IBU and NPX in relatively low concentrations with median values between 1.2 and $44.8 \mathrm{ng} / \mathrm{L}$, and their recovery rates varied between $81.5 \%$ and $106.0 \%$. Increasing levels of concentrations of the seven compounds were observed in the samples collected from tributaries Jiu, Olt and Argeș, downstream of the big cities, as opposed to upstream values, highlighting the contribution of the municipal effluents.

Detected levels of DCF, KET, NPX, IBU in the Danube and tributaries were comparable to those reported for Danube River and Argeș tributary [27].

DCF, a highly prescribed anti-inflammatory drug with proved mutagenic effects included in the priority substances list, was found in all 3 sampling campaigns in concentrations ranging from $0.8 \mathrm{ng} / \mathrm{L}$ to $7.5 \mathrm{ng} / \mathrm{L}$, and detection frequencies between $50 \%$ and $100 \%$. Triclosan and triclocarban, highly used disinfectants in personal care products such as soap or toothpaste, were both found with a $100 \%$ detection frequency in April, in median concentration of $2.7 \mathrm{ng} / \mathrm{L}$ and $3.6 \mathrm{ng} / \mathrm{L}$, respectively.

TCS was detected in the surface waters of Spain in higher concentration than in this investigation (ND-223 ng/L) [28] and up to $95 \mathrm{ng} / \mathrm{L}$ in UK [29]. TCC levels detected in Central Spain Rivers being up to $20 \mathrm{ng} / \mathrm{L}$ were similar to those determined in this study [28].

A total of 18 pharmaceuticals belonging to different therapeutic classes were studied in a sampling campaign performed in February 2014 [25]: an analgesic (ACE), an anti-epileptic drug (CBZ), a nervous stimulant (CAF) and 15 antibiotics: TRI, SMX, CIP, norfloxacin (NOR), azithromycin (AZI), erythromycin (ERY), roxithromycin (ROX), ampicillin (AMP), cephalexin (CEF), amoxicillin (AMX), penicillin $\mathrm{G}$ (PEN G), penicillin V (PEN V), oxacillin (OXA), ofloxacin (OFL), clarithromycin (CLA). CAF, CBZ, TRI, CIP, SMX, CLA and CEF were the pharmaceuticals found in investigated samples. Their ranges of concentration, median and frequencies are presented in Table 5.

Table 5. Range and median of pharmaceutical concentrations and detection frequency of individual pharmaceuticals from surface water samples

\begin{tabular}{|lccc|}
\hline \multicolumn{1}{|c}{ Compound } & Range $(\mathbf{n g} / \mathbf{L})$ & ${\text { Median } \pm \mathbf{I Q R}(\mathbf{n g} / \mathbf{L})^{\mathbf{a}}}^{\mathbf{a}}$ & Frequency $(\%)^{\mathbf{b}}$ \\
\hline Caffeine & $28.3-128.0$ & $76.4 \pm 35.6$ & 100 \\
Carbamazepine & $5.4-15.4$ & $9.65 \pm 6.1$ & 100 \\
Sulfamethoxazole & $3.2-15.7$ & $7.9 \pm 2.4$ & 87 \\
Clarithromycin & $1.2-23.2$ & $3.0 \pm 2.7$ & 75 \\
Trimethoprim & $1.3-11.1$ & $2.6 \pm 1.2$ & 69 \\
Cephalexin & $5.6-17.8$ & $9.9 \pm 4.6$ & 50 \\
Ciprofloxacin & $3.6-4.8$ & $3.7 \pm 0.6$ & 19 \\
\hline
\end{tabular}

a IQR-interquartile range

${ }^{\mathrm{b}}$ Percentage of particular pharmaceuticals in 16 sampling sites 


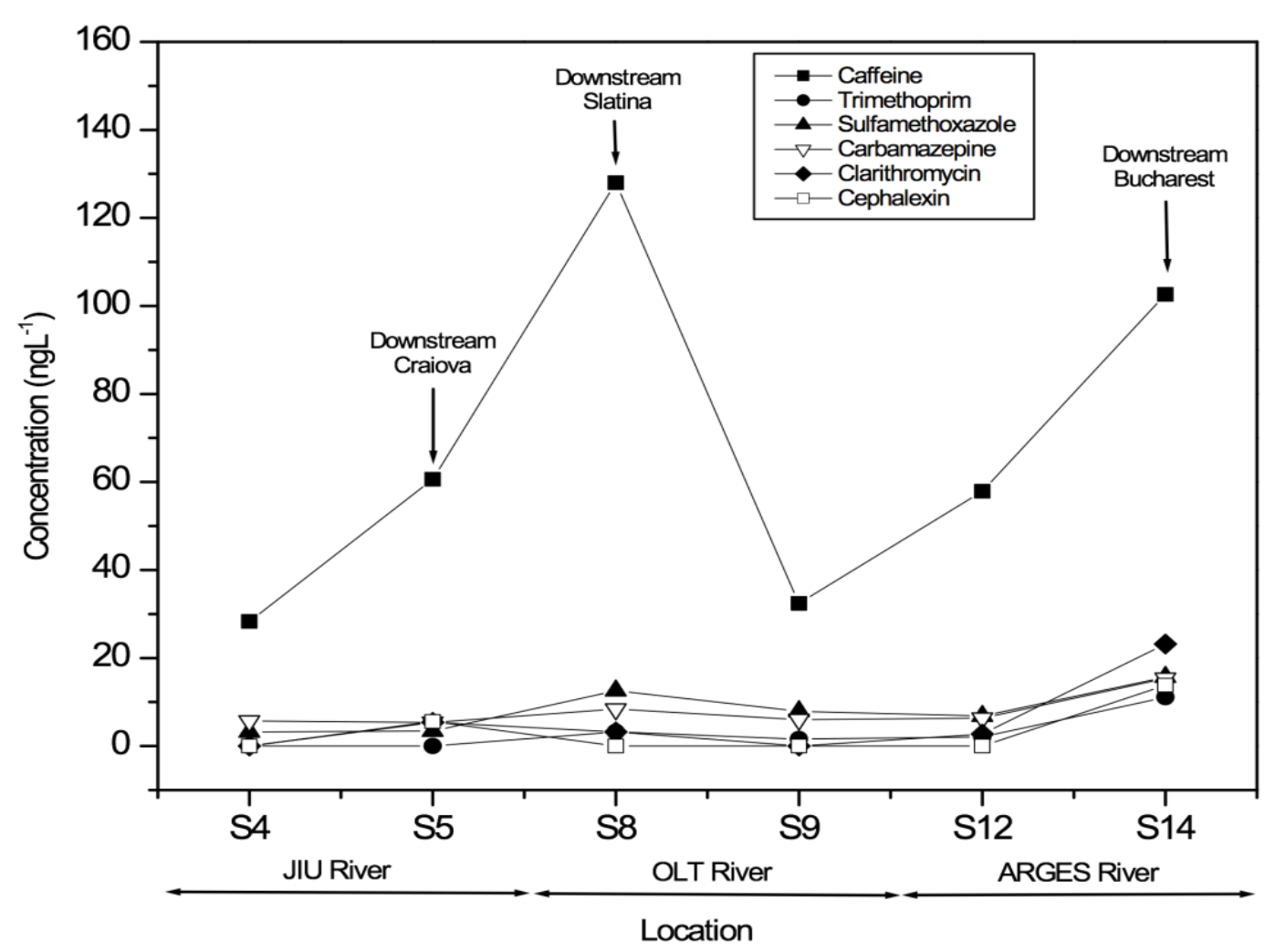

Fig. 5. Concentrations of pharmaceuticals detected in Danube River tributaries

Figure 5 shows the scatter plots of individual pharmaceutical concentration versus sampling points on Jiu, Olt and Argeș rivers. As depicted in the figure below, the most contaminated samples were collected from tributary rivers downstream of big cities like Craiova (Jiu River), Slatina (Olt River) and Bucharest (Argeș River).

$\mathrm{CAF}$ and $\mathrm{CBZ}$ were also detected in this investigation in all surface water samples in concentrations which varied from 28.3 to 128 $\mathrm{ng} / \mathrm{L}$ and from 5.4 to $15.1 \mathrm{ng} / \mathrm{L}$, respectively. Taking into account their ubiquitous occurrence in WWTP effluents, CAF and CBZ are considered markers of surface water pollution [30].

The CBZ anticonvulsant, found in the surface waters of Romanian Danube River basin, had similar concentrations to those reported for surface waters in Serbia (6-130 ng/L) [31]. The high frequency detection of CBZ in river waters is explained by its low removal rate in WWTPs and by its high resistance in the aquatic environment [31].

SMX and TRI, usually used in combination pharmaceutical formulations, are among the antibiotics most frequently detected in surface waters, in concentrations of $69 \%$ and $87 \%$ respectively. The fairly regular occurrence of SMX and TRI in the collected sample is consistent with the compounds occurrence in the upper Tennessee River basin [32] and Douro River estuary (Portugal) [33]. Their high degree of persistence in natural waters is explained by their low values of $\log \mathrm{K}_{\mathrm{ow}}$ of 0.91 (TRI) and 0.89 (SMX) [34]. Similar concentrations of TRI and SMX were found in the surface waters of Canal Danube-Tisa-Danube from Serbia [35] and in the surface waters of the Henares-JaramaTajo River system (Madrid, Spain) [36].

Fluctuations of pharmaceutical concentrations in the Danube River waters were observed downstream of the Argeș river discharges, the most contaminated tributary. TRI, SMX, CLA and CEF, which were not detected upstream of the Argeș river discharge, occurred downstream of the confluence in concentrations ranging from $1.3 \mathrm{ng} / \mathrm{L}$ to $15.9 \mathrm{ng} / \mathrm{L}$. Estrogen hormones levels in surface water of Danube River and the three tributaries were tested during a sampling campaign carried out in October 2015 using a newly developed LC-ESI (-)-MS/MS method with automated SPE extraction [26]. The investigated compounds were: Equilin (Eq), Estrone (E1), $17 \alpha$-Estradiol $(\alpha \mathrm{E} 2), 17 \beta$-Estradiol ( $\beta E 2), 17 \alpha$-Ethinylestradiol (EE2), Estriole (E3). 
$\mathrm{E} 3, \mathrm{Eq}$ and $\alpha$-E2 are compounds that were not detected in any of the analyzed samples, while E1, $\beta$-E2 and EE2 were determined in all the samples at concentrations ranging from $0.5 \mathrm{ng} / \mathrm{L}$ to a maximum of $3.7 \mathrm{ng} / \mathrm{L}$. In the graph presented in Fig. 6, it can be observed that the Estrone steroid was found in higher levels of concentration than its quantification limit (1.0 $\mathrm{ng} / \mathrm{L}$ ) in samples taken along the Danube River, with concentrations ranging from 1.2 to 1.6 $\mathrm{ng} / \mathrm{L}$. An explanation of the low level of $\beta \mathrm{E} 2$ in the tested river water can be the result of the easy transformation of $\beta$-E2 into estrone in the environment through oxidation [37]. Higher values of estrone, up to $3.8 \mathrm{ng} / \mathrm{L}$, were determined in tributaries downstream of major cities like Craiova and Bucharest when compared to upstream values (Fig. 7). This easily explains the contribution of their WWTPs to surface water pollution. Estrogen hormones levels in Danube water and its tributaries are generally comparable in magnitude order with those reported in other studies within Europe, with levels ranging from $<0.3$ to $4.9 \mathrm{ng} / \mathrm{L}$ [38,39].

\section{CONCLUSIONS}

Nowadays, in the absence of solutions that could effectively prevent the pollution of the natural waters of our country, it is important to monitor the level of contamination from pharmaceuticals, especially from antibiotics and endocrine disrupting substances. The studies show that some pharmaceuticals and disinfectants are not completely eliminated in the municipal WWTPs and therefore they enter the aquatic environment. A nervous stimulant and a psychiatric drug, caffeine and carbamazepine respectively, were found in all surface water samples. Occurrences with a frequency higher than $50 \%$ were observed in collected samples for sulfamethoxazole, trimethoprim, clarithromycin and cephalexin. The development and implementation of more efficient wastewater treatment processes, fit to remove organic contaminants such as the pharmaceutical compounds from effluents discharges in natural emissaries, should be the key to reducing the spread of these contaminants in the Romanian aquatic environment.

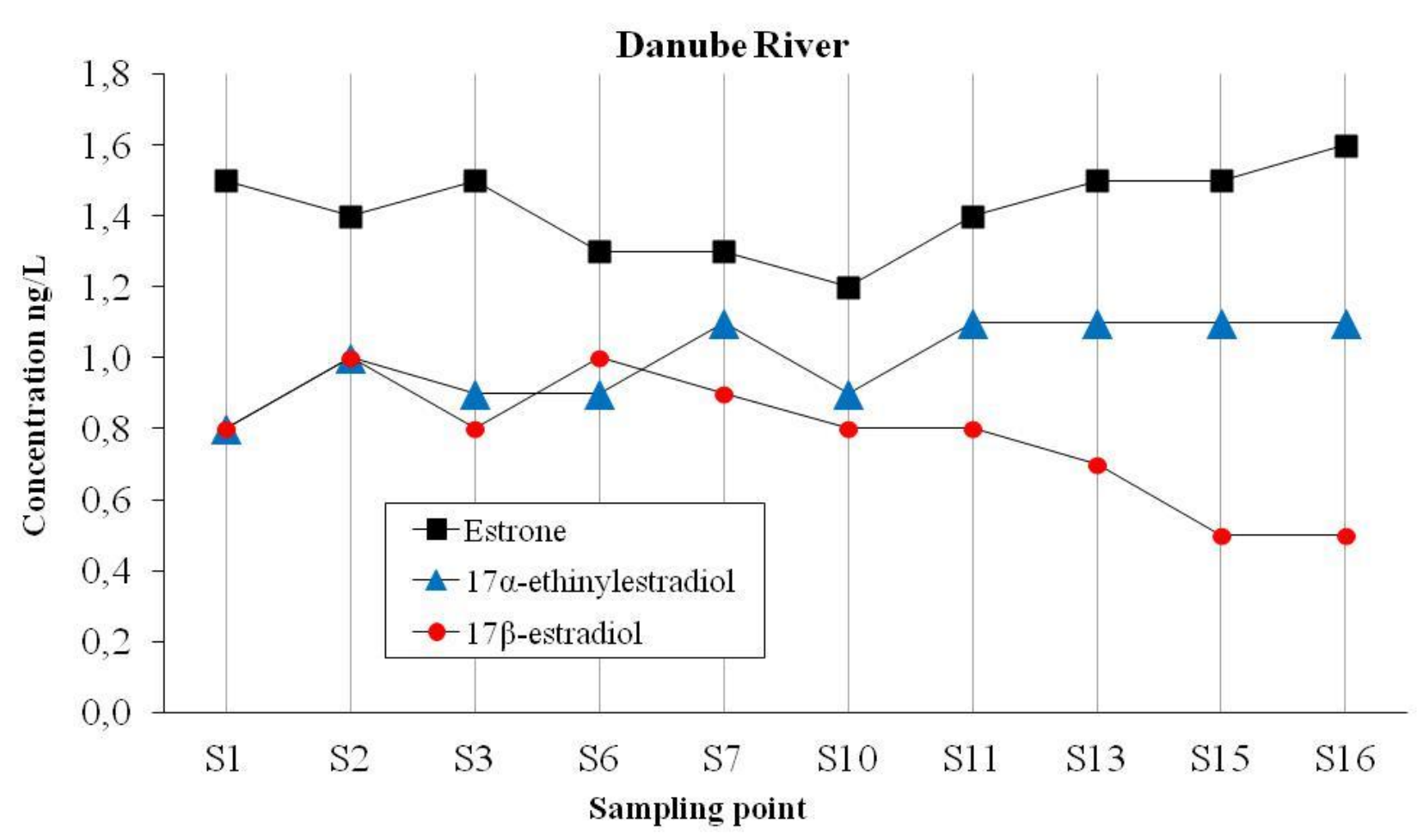

Fig. 6. Estrogen hormones levels (ng/L) detected along the Danube River 


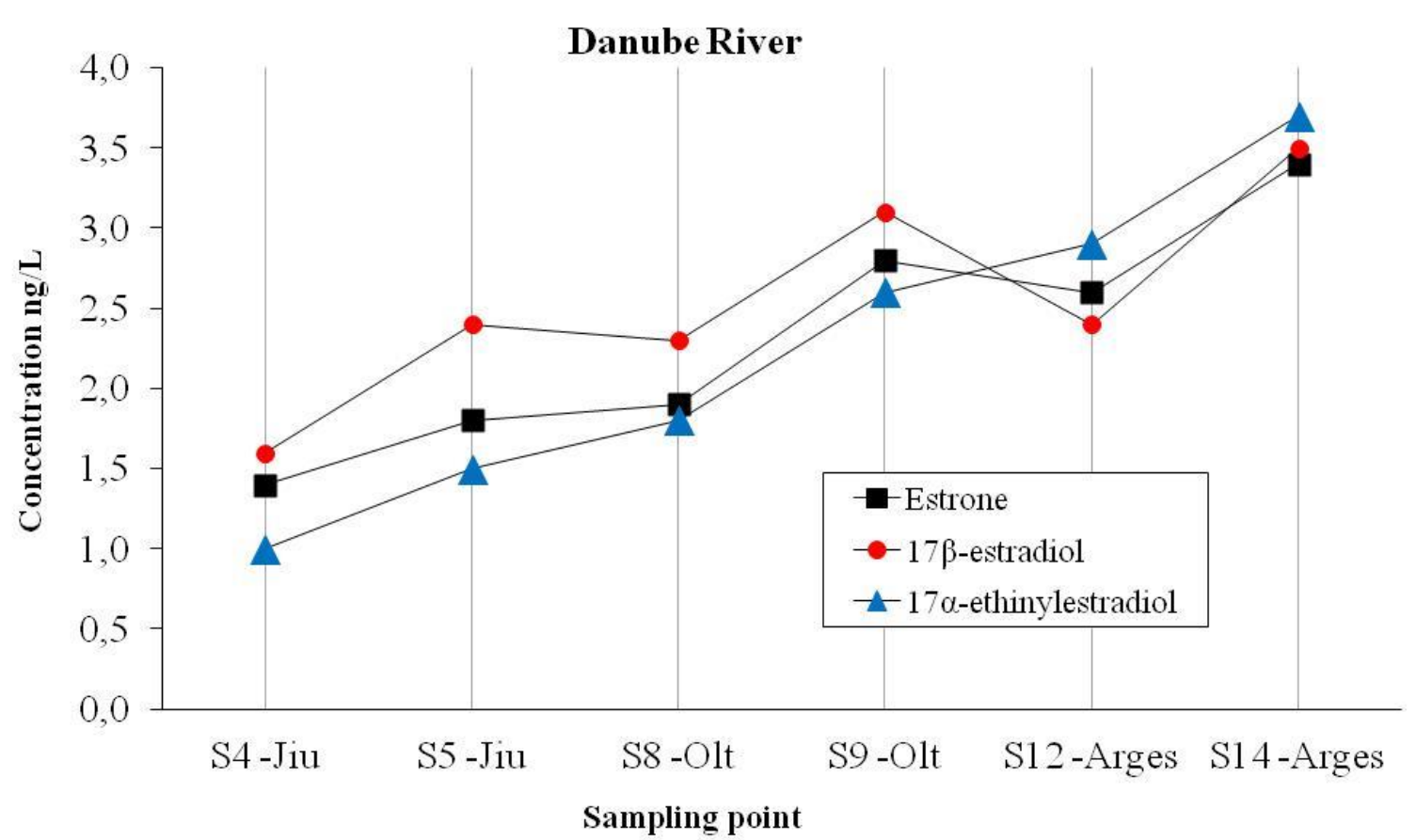

Fig. 7. Estrogen hormones levels (ng/L) detected in Jiu, Olt and Argeș tributaries

ACKNOWLEDGEMENTS. The work has been funded by The Program Nucleu 13N/2009, Project code: PN 09-130109.

\section{REFERENCES}

1. OBST, U., SCHWATZ, T., VOLKMANN, H., Int J Artif Organs, 29, no.4, 2006, p. 387.

2. LIU, S., YING, G.-G, ZHAO, J.-L., CHEN, F., YANG, B., ZHOU, J., LAI, H.-J., J Chromatogr. A, 1218, 2011, p. 1367.

3. COSTANZO, S.D., MURBY, J., BATES, J., Mar. Pollut. Bull., 51(1-4), 2005, p. 218.

4. DOLEJSKA, M., FROLKOVA, P., FLOREK, M., JAMBOROVA, I., PURGERTOVA, M., KUTILOVA, I., CIZEK, A., GUENTHER, S., LITERAK, I., J. Antimicrob. Chemother., 66, 2011, p. 2784.

5. HARNISZ, M., GOLAS, I., PIETRUK, M., Ecol. Indic., 11, 2011, p. 663.

6. GRACIA-LOR, E., CASTIGLIONI, S., BADE, R., BEEN, F., CASTRIGNANO, E., COVACI, A., GONZALEZ-MARINO, I., HAPESHI, E., KASPRZYK-HORDERN, B., KINYUA, J., LAI, F.Y., LETZEL, T. LOPARDO, L., MEYER, M.R., O'BRIEN, J., RAMIN, P., ROUSIS, N.I., RYDEVIK, A., RYU, Y., SANTOS, M.M., SENTA, I., THOMAIDIS, N.S., VELOUTSOU, S., YANG, Z., ZUCCATO, E., BIJLSMA, L., Environ. Int. 99, 2017, p. 131.

7. *** Official Journal of the European Union, 7.6.2018, no. L 141, p. 9.

8. CASTIGLIONI, S., BAGNATI, R., FANELLI, R., POMATI, F., CALAMARI, D., ZUCCATO, E., Environ. Sci. Technol. 40, 2006, p. 357.

9. LOGANATHAN, B., PHILliPS, M., MOWERY, H., JONES-LEPP, T.L., Chemosphere, 75, 2009, p. 70.

10. WATKINSON, A.J., MURBY, E.J., COSTANZO, S.D., Water Res., 41, 2007, p. 4164.

11. LACEY, C., MC MAHON, G., BONES, J., BARRON, L., MORRISSEY, A., TOBIN, J.M., Talanta, 75, 2008, p. 1089.

12. SZYMANSKA, U., WIERGOWSKI, M., SOLTYSZEWSKI, I., KUZEMBO, J., WIERGOWSKA, G., WOZNIAK, M.K., Microchem J, 147, 2019, p. 729.

13. KOSMA, C.I., LAMBROPOULOU, D.A., ALBANIS, T.A., Sci. Total Environ. 466-467, 2014, p. 421. 
14. GROS, M., RODRIGUEZ-MOZAZ, S., BARCELO, D., J. Chromatogr. A, 1292, 2013, p. 173.

15. MADUREIRA, T.V., BARREIRO, J.C., ROCHA, M.J., ROCHA, E., CASS, Q.B., TIRITAN, M.E., Sci. Total Environ., 408, 2010, p. 5513.

16. GOLOVKO, O., KUMAR, V., FEDOROVA, G., RANDAK, T., GRABIC, R., Chemosphere, 111, 2014, p. 418.

17. PETRE, J., IANCU, V.I., VASILE, G.G., ALBU, F., NICULESCU, M., NICULAE, A.C., CRUCERU, L., NICOLAU, M., SGEM 2013 Conference Proceedings, ISBN 978-6197105-04-9, vol I, 2013, p. 71.

18. BENDZ, D., PAXEUS, N.A., GINN, T.R., LOGEC, F.J., J. Hazard. Mater., 122, 2005, p. 195.

19. ZHOU, J.L., ZHANG, Z.L., BANKS, E., GROVER, D., JIANG, J.Q., J. Hazard. Mater.,166, 2009, p. 655.

20. JOSS, A., KELlER, E., ALDER, A.C., GOBEL, A., MCARDELL, C.S., TERNES, T.A., SIEGRIST, H., Water. Res., 39, 2005, p. 3139.

21. ZHANG, Y., GEIBEN, S.-U., GAL, C., Chemosphere, 73, 2008, p. 1151.

22. GULKOVSKA, A., LEUNG, H.W., SO, M.K., TANIYASU, S., YAMASHITA, N., YEUNG, L. W.Y., RICHARDSON, B. J., LEI, A.P., GIESY, J.P., LAM, P.K.S., Water Res., 42, 2008, p. 395.

23. PETRE, J., GALAON, T., IANCU, V.I., CRUCERU, L., NICULESCU, M., J Environ Prot Ecol, 17, no 1, 2016, p. 119.

24. PETRE, J., IANCU, V.I., STANESCU, E., SGEM 2015, Conference Proceedings, ISBN 978-619-7105-40-7, Book 5 Vol. 2, 2015, p. 301.

25. PETRE, J., GALAON, T., IANCU, V.I., VASILE G.G., STANESCU, E., PASCU, L.F., SIMION, M., CRUCERU, L., Rev. Chim. (Bucharest), 67, 8, 2016, p. 1436.

26. GALAON, T., PETRE, J., IANCU, V.I., CRUCERU, L., VASILE G.G., PASCU, L.F., LEHR, C.B., Revista de Chimie, 67, 8, 2016, p. 1474.

27. LOOS R., LOCORO G., CONTINI S., Water Res., 44, 2010, p. 2325.

28. ESTEBAN S., GORGA M., PETROVIC M., GONZALEZ-ALONSO S., BARCELO D., VALCARCEL Y., Sci. Total Environ., 466-467, 2014, p. 939.

29. KASPRZYK-HORDERN B., DINSDALE R.M., GUWY A.J., Water Res., 42, 2008, p. 3498.

30. AYDIN, E., TALINLI, I., Chemosphere, 90, 2013, p 2004.

31. GRUJIC, S., VASILJEVIC, S., LAUSEVIC, T., M., J. Chromatogr. A, 1216, 2009, p 4989.

32. CONLEY, J. M., SYMES, S. J., SCHORR, M. S., RICHARDS, S. M., Chemosphere, 73, 2008, p 1178.

33. MADUREIRA, T. V., BARREIRO, J. C., ROCHA, M. J., ROCHA, E., CASS, Q. B., TIRITAN, M. E., Sci. Total. Environ., 408, 2010, p 5513.

34. BENDZ, D., PAXEUS, N. A., GINN, T. R., LOGE, F. J., J. Hazard. Mater., 122, 2005, p 195.

35. PETROVIC, M., SKRBIC, B., ZIVANCEV, J., FERRANDO-CLIMENT, L., BARCELO, D., Sci. Total. Environ., 468-469, 2014, p 415.

36. FERREIRA DA SILVA, B., JELIC, A., LOPEZ-SERNA, R., MOZETO, A.A., PETROVIC, M., BARCELO, D., Chemosphere, 85, 2011, p 1331.

37. AGA, D.S., Fate of Pharmaceuticals in the Environment and in Water Treatment Systems, CRC Pres, London, 2008, p. 300.

38. BOGI, C., SCHWAIGER, J., FERLING, H., MALLOW, U., STEINECK, C., SINOWATZ, F., KALBFUS, W., NEGELE, R.D., LUTZ, I., KLOAS, W., Environ. Res., 93, 2003, p. 195.

39. GORGA, M., PETROVIC, M., BARCELO, D., J. Chromatogr. A, 1295, 2013, p. 57. 